Research Article

\title{
Comparison of serum corrected and ionized calcium levels in patients with acute kidney injury
}

Akut böbrek hasarı olan hastalarda serum düzeltilmiş ve iyonize kalsiyum seviyelerinin karşılaştırılması

Canan Akman ${ }^{\mathrm{a}}$, Derkan Bakirdogen ${ }^{\mathrm{b}}$, Murat Das $^{\mathrm{a}}$, Serdal Balci ${ }^{\mathrm{c}}$, Okyanus Necdet Aykan ${ }^{\mathrm{d}}$

${ }^{\text {a }}$ Canakkale Onsekiz Mart University, School of Medicine, Department of Emergency Medicine, Canakkale, Turkey

b Canakkale Onsekiz Mart University, School of Medicine, Department of Nephrology, Canakkale, Turkey

c Sirnak State Hospital, Emergency Service, Sirnak, Turkey

${ }^{\mathrm{d}}$ Kastamonu State Hospital, Emergency Service, Kastamonu, Turkey

\begin{abstract}
Introduction: Acute kidney injury (AKI) is common in hospitalized patients (1.92\%). The effect of serum corrected and ionized calcium levels in predicting emergency hemodialysis in patients with AKI is unknown. In this study, we aimed to compare serum corrected and ionized calcium levels in patients who were diagnosed with AKI in the emergency service.

Methods: Our study was planned retrospectively. Group 1: Patients with AKI who underwent at least one session of emergency hemodialysis. Group 2: The patients with AKIN stage 1-3 who did not undergo hemodialysis. Serum corrected and ionized calcium, creatinine and albumin values of the patients at the time of admission were analyzed. All data of the study were recorded by SPSS 19.0. For statistical significance, $\mathrm{p}$ $<0.050$ was accepted.

Results: The mean serum corrected calcium levels were lower in group 1 than in group 2 , and the difference was statistically significant ( $<<0.001$ ). The mean ionized calcium levels in blood gas were lower in group 1 than in group 2 , and the difference was statistically significant $(p=0.002)$.

Conclusions: Serum corrected, and ionized calcium levels can be useful in predicting emergency hemodialysis in patients with AKI.

Keywords: Calcium, acute kidney injury, emergency medical service
\end{abstract}

\section{$\ddot{O} \mathbf{z}$}

Giriş: Hastaneye yatırılan hastalarda akut böbrek hasarı (ABH) sık olarak görülmektedir (\%1,92). ABH'lı hastalarda serum düzeltilmiş ve iyonize kalsiyum düzeylerinin acil hemodiyalizi öngörmedeki etkisi bilinmemektedir. Bu çalışmada acil serviste $\mathrm{ABH}$ tanısı alan hastalarda serum düzeltilmiş ve iyonize kalsiyum düzeylerini karşılaştırmayı amaçladık.

Yöntem: Çalışmamız retrospektif olarak planlandı. Grup 1: En az bir kez acil hemodiyaliz seansı alan ABH hastaları. Grup 2: Hemodiyalize girmeyen AKIN evre 1-3 olan hastalar. Hastaların başvuru anında serum düzeltilmiş ve iyonize kalsiyum, kreatinin ve albümin değerleri incelendi. Çalışmanın tüm verileri SPSS 19.0 ile kaydedildi. İstatistiksel anlamlılık için $\mathrm{p}<0,050$ kabul edildi.

Bulgular: Serum düzeltilmiş kalsiyum düzeylerinin ortalaması grup 1'de grup 2'ye göre daha düşüktü ve fark istatistiksel olarak anlamlıydı (p $<0,001)$. Kan gazındaki ortalama iyonize kalsiyum seviyeleri grup 1'de grup 2'ye göre daha düşüktü ve fark istatistiksel olarak anlamlıydı $(\mathrm{p}=$ 0,002).

Sonuç: ABH hastalarında acil hemodiyalizin öngörülmesinde serum düzeltilmiş ve iyonize kalsiyum düzeyleri faydalı olabilir. Anahtar kelimeler: Kalsiyum, akut böbrek hasarı, acil servis

\begin{tabular}{|c|c|c|c|c|}
\hline Received & Accepted & Published Online & Corresponding Author & E-mail \\
\hline January 5,2021 & April 2, 2021 & May 5, 2021 & Canan Akman, M.D. & drcananakman@ gmail.com \\
\hline Correspondence & \multicolumn{2}{|l|}{$\begin{array}{l}\text { Dr. Canan Akman, Çanakkale Onsekiz Mart Üniversitesi Sağllk Uygulama ve Araştırma Hastanesi Acil } \\
\text { Tip AD. Barbaros Mah., Prof. Dr. Sevim Buluç Sk. No:2, 17110 Merkez/Çanakkale, Turkey }\end{array}$} \\
\hline
\end{tabular}




\section{Introduction}

Acute kidney injury (AKI) is a common complication among hospitalized patients. The frequency of AKI was found to be 19.2 per 1000 hospitalizations [1,2] Acute Kidney Injury Network (AKIN) criteria has been recently used for staging AKI. AKIN criteria are based on serum creatinine and urine output values [3]. There is still a lack of consensus on the indication for renal replacement therapy (RRT) in acute kidney injury [4]. Disruptions in calcium and phosphorus balance may occur in AKI but these problems are usually chronic. Acidosis associated with renal failure affects the albumin-calcium complex and increases serum ionized calcium levels [5]. Of the patients manifesting AKI during hospitalization, $26.4 \%$ developed hypocalcemia, 56.3\% developed normocalcemia, and $17.3 \%$ developed hypercalcemia [6]. The predictive effect of the serum corrected and ionized calcium levels on the patients with AKIN stage 3 is not known. In this study, we aimed to compare serum corrected and ionized calcium levels in patients who were diagnosed with AKI in the emergency service.

\section{Methods}

\section{Ethical approval, informed consent and permissions}

Our study was planned retrospectively. Our study started after the approval of the local ethics committee (date:28.11.2018 - number: 2018-21).

\section{Study Design}

The patients with AKI admitted to the emergency service between August and December 2018 were included in the study. AKIN criteria have been adopted for AKI classification in our study [7]. Written consent was obtained from each patient. Inclusion criteria included the patients aged between 50-80 years and diagnosed with AKI were included (serum creatinine value of $1.5 \mathrm{mg} / \mathrm{dl}$ or more).

Exclusion criteria included patients younger than 50 or older than 80 years, having a previous dialysis or a history of end-stage renal disease (ESRD) and malignancy. The patients were divided into two groups:

Group 1: Patients with AKI who underwent at least one session of emergency hemodialysis.

Group 2: The patients with AKIN stage 1-3 who did not undergo hemodialysis.

Group 1a: It was created in AKI patients with serum creatinine> $4 \mathrm{mg} / \mathrm{dL}$ and received at least one hemodialysis session.

Group 2a: It was formed from AKI patients with serum creatinine> 4mg / dL and without hemodialysis indication.

Regardless of the serum creatinine level, at least one session of hemodialysis in AKI patients was accepted as stage 3 according to AKIN criteria [3].

\section{Laboratory Analysis}

The serum calcium, ionized calcium, creatinine and albumin values of the patients at the time of admission were analyzed in the laboratory. Blood samples for serum creatinine and albumin were collected in vacuum gel tubes while samples for serum calcium were collected in EDTA tubes. These samples were incubated at room temperature for 30 minutes and then centrifuged at $4000 \mathrm{rpm}$ for 10 minutes. Creatinine was estimated by enzymatic method; albumin was determined by colorimetric method; calcium was estimated by photometric method with a Cobas c501 analyzer and using Roche kits (Roche Diagnostics $\mathrm{GmbH}$ ) on the same day. Venous blood gas samples were used to measure ionized calcium. Ionized calcium was monitored using blood gas analyzers. The ABL 725 (Radiometer Copenhagen) was used for the analysis and ISEs (ion selective electrodes) were used for the measurement.

\section{Statistical Analysis}

The data of this study were recorded using SPSS 19.0 (SPSS Inc., Chicago, IL, USA) and statistically analyzed. The descriptive data was presented using number, percentage, mean, standard deviation, median, minimum, and maximum. Chi-square test was employed for the comparison of the categorical data. The normality of data distribution was evaluated by Kolmogorov Smirnov Test. Of numerical variables with abnormal distribution, for two-group and subgroups comparisons Mann-Whitney U test was used. For statistical significance, p $<0.05$ was accepted. All analyzes applied in the research are nonparametric analysis.

\section{Results}

A total of 162 (including 54 in group 1 and 108 in group 2) patients participated in the study. Group 1 had 32 men and 22 women. Group 2 had 58 men and 50 women. The mean age of group 1 was $70.7 \pm 15.7$ and the mean age of group 2 was $73.2 \pm 13.2$. There was no statistically significant difference between the two groups in terms of gender and age ( $>0.050)$. The mean corrected serum calcium levels of Group 1 were lower than that of Group 2 and the difference was statistically significant $(\mathrm{p}<0.001)$. The mean ionized calcium levels of Group 1 were found lower than that of Group 2 in blood gas analysis and the difference was statistically significant ( $\mathrm{p}=0.002)$. Also, the mean serum creatinine values of Group 1 were higher than that of Group 2 and the difference was statistically significant $(p<0.001)$. The mean serum albumin values of Group 1 were lower than that of Group 2 and the difference was statistically significant $(\mathrm{p}=0.014)$. The biochemical values of the patients groups are given in table 1 . 
Table 1. The biochemical values of the patients groups

\begin{tabular}{|c|c|c|c|c|c|}
\hline \multirow{2}{*}{ Biochemical Values } & \multirow{2}{*}{$\begin{array}{c}\text { Group } 1(n=54) \\
\bar{X} \pm \text { SD } \\
\end{array}$} & \multicolumn{3}{|c|}{ Group $2(n=108)$} & \multirow[b]{2}{*}{$\mathbf{p}$} \\
\hline & & Median (Min-Max) & $\overline{\bar{X}} \pm$ SD & Median (Min-Max) & \\
\hline $\begin{array}{l}\text { Ionized calcium } \\
(\mathrm{mmol} / \mathrm{L})\end{array}$ & $1.0 \pm 0.3$ & $1.1(0.5-2.2)$ & $1.1 \pm 0.2$ & $1.1(0.5-2.0)$ & 0.002 \\
\hline $\begin{array}{l}\text { Corrected serum calcium } \\
(\mathrm{mg} / \mathrm{dL})\end{array}$ & $8.5 \pm 2.3$ & $8.2(5.1-22.0)$ & $8.9 \pm 0.9$ & $8.9(5.1-12.3)$ & $<0.001$ \\
\hline $\begin{array}{l}\text { Serum albumin } \\
(\mathrm{g} / \mathrm{dL})\end{array}$ & $2.9 \pm 0.7$ & $2.9(1.5-4.3)$ & $3.2 \pm 0.7$ & $3.4(2.5-5.1)$ & $<0.001$ \\
\hline $\begin{array}{l}\text { Serum creatinine } \\
(\mathrm{mg} / \mathrm{dL})\end{array}$ & $4.7 \pm 3.0$ & $3.6(1.6-12.5)$ & $2.9 \pm 1.6$ & $2.6(0.4-6.8)$ & $<0.001$ \\
\hline
\end{tabular}

p: Mann Whitney U Test, $\bar{X}:$ Mean, SD: Standard Deviation, Min: Minimum, Max: Maximum

Among the patients with serum creatinine level $>4 \mathrm{mg} / \mathrm{dL}$, two different subgroups were formed: those who received at least one hemodialysis session (group 1a) and those who did not (group 2a). When the two subgroups were compared with each other in terms of gender, no statistically significant difference was found $(\mathrm{p}=0.133)$. The comparison of age and serum biochemistry results of patient subgroups are shown in Table 2 .

Table 2. Comparison of age and serum biochemical values of patient subgroups

\begin{tabular}{|c|c|c|c|c|c|c|}
\hline & & $\mathbf{N}$ & $\bar{X} \pm \mathbf{S D}$ & Median (Min-Max) & $\mathbf{U}$ & $\mathbf{p}$ \\
\hline \multirow{2}{*}{ Age (year) } & Group 2a & 26 & $71.6 \pm 12.9$ & $73(41-91)$ & \multirow{2}{*}{302} & \multirow{2}{*}{0.846} \\
\hline & Group 1a & 24 & $71.2 \pm 17.2$ & $73(24-92)$ & & \\
\hline \multirow{2}{*}{$\begin{array}{l}\text { Serum creatinine } \\
(\mathrm{mg} / \mathrm{dL})\end{array}$} & Group 2a & 26 & $5.5 \pm 1.9$ & $4.9(4.1-13.3)$ & \multirow{2}{*}{146} & \multirow{2}{*}{$<0.001$} \\
\hline & Group 1a & 24 & $7.4 \pm 2.6$ & $6.7(4.2-12.5)$ & & \\
\hline \multirow{2}{*}{$\begin{array}{l}\text { Ionized calcium } \\
(\mathrm{mmol} / \mathrm{L})\end{array}$} & Group 2a & 26 & $1.1 \pm 0.3$ & $1.2(0.4-1.9)$ & \multirow{2}{*}{223} & \multirow{2}{*}{0.084} \\
\hline & Group 1a & 24 & $1.0 \pm 0.2$ & $1.1(0.6-1.3)$ & & \\
\hline \multirow{2}{*}{$\begin{array}{l}\text { Corrected serum calcium } \\
(\mathrm{mg} / \mathrm{dL})\end{array}$} & Group $2 \mathrm{a}$ & 23 & $9.4 \pm 0.6$ & $9.4(8.4-10.5)$ & \multirow{2}{*}{164} & \multirow{2}{*}{0.027} \\
\hline & Group 1a & 23 & $9.0 \pm 1.3$ & $8.9(6.6-13.7)$ & & \\
\hline \multirow{2}{*}{$\begin{array}{l}\text { Serum albumin } \\
(\mathrm{g} / \mathrm{dL})\end{array}$} & Group 2a & 23 & $3.2 \pm 0.7$ & $2.9(2-4.4)$ & \multirow{2}{*}{205} & \multirow{2}{*}{0.191} \\
\hline & Group 1a & 23 & $2.9 \pm 0.6$ & $2.8(2-4.2)$ & & \\
\hline
\end{tabular}

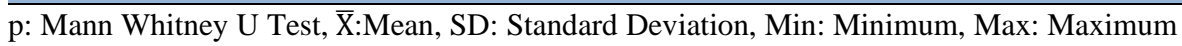

According to this, serum creatinine level was higher in group 1a patients and corrected calcium level was higher in group 2a. The results were statistically significant $(p<0.005)$. Subgroups were similar in terms of age, serum albumin and ionized calcium levels $(p>0.005)$.

\section{Discussion}

There is insufficient evidence to show the effect of serum calcium and ionized calcium levels in emergency hemodialysis decisions in AKIN (stage2-3) patients. Dialysis is considered as the last treatment option in patients with severe hypercalcemia associated with renal failure [8]. AKI was more common in the hypocalcemic group than in the non-hypocalcemic group in patients with rhabdomyolysis [9]. In another study of ours which was a prospective study with patients with AKIN stage 3, serum calcium and ionized calcium levels of the group who received emergency hemodialysis were lower than that of those who did not undergo hemodialysis [10]. This retrospective study showed similar results. It concluded that serum corrected and ionized calcium levels of the patients with AKI who referred to the emergency unit and received hemodialysis based on clinical indications were lower than that of the patients who did not undergo hemodialysis. In our study, when patients with serum creatinine> $4 \mathrm{mg} / \mathrm{dL}$ due to acute renal failure were divided into two subgroups as dialysis (group 1a) and non-dialysis (group 2a), serum creatinine levels were higher in group 1a and corrected calcium levels were higher in group 2a patients. The groups were found to be similar in terms of serum albumin and ionized calcium levels. The findings of our study are compatible with the literature. As an exception, ionized calcium levels were found to be similar in both subgroups, the lower ionized calcium levels of group 1a patients than group 2a patients, although not reaching statistical significance, may be due to the low number of participants [10].

There is still a lack of consensus as to when RRT should be initiated in patients with AKI [4, 11]. Increase in serum creatinine level is important for the diagnosis of AKI [7]. This study indicated that the mean serum creatinine levels of the patient group receiving RRT were higher relative to the other group. Hypoalbuminemia is independently associated with increased risk of AKI in patients suffering from severe physical illness [12]. Hypoalbuminemia may contribute to development of AKI. Human albumin solutions used in the treatment of hypoalbuminemia can prevent development of AKI $[13,14]$. This study revealed that the mean serum albumin levels of group 1 were lower than that of the other group. 


\section{Limitations}

This study has several limitations. The study group consisted of a small number of patients and did not include a control group receiving RRT due to ESRD. Serum parathormone, 25-OH Vitamin D3, phosphorus, magnesium and urinary calcium levels of the patients were not measured.

\section{Conclusion}

Serum corrected and ionized calcium levels of the patients with AKI who referred to the emergency service and received hemodialysis were lower than that of the patients who did not undergo hemodialysis. Serum corrected and ionized calcium levels can be useful in predicting emergency hemodialysis in patients with AKI. Prospective, randomized and controlled studies are needed in this area.

Conflict of interest: None

Financial support: None

\begin{tabular}{|l|r|l|}
\hline \multicolumn{2}{|c|}{ Author Contributions } & \multicolumn{1}{c|}{ Author Initials } \\
\hline SCD & Study Conception and Design & CA, SB, SBa, MD \\
\hline AD & Acquisition of Data & CA, SB, ONA \\
\hline AID & Analysis and Interpretation of Data & CA, SB, SBa, ONA \\
\hline DM & Drafting of Manuscript & CA, SB, MD, SBa \\
\hline CR & Critical Revision & CA, SB, MD, ONA \\
\hline
\end{tabular}

Prior publication: Our study was presented as an oral presentation at the Thrace Universities Association 3rd International Health Sciences Congress held in Canakkale on 24-26 October 2019.

\section{References}

1. Liangos O, Wald R, O’Bell JW, Price L, Pereira BJ, Jaber BL. Epidemiology and outcomes of acute renal failure in hospitalized patients: a national survey. Clin J Am Soc Nephrol 2006; 1(1):43-51. https://doi.org/10.2215/CJN.00220605

2. Chertow GM, Burdick E, Honour M, Bonventre JV, Bates DW. Acute kidney injury, mortality, length of stay, and costs in hospitalized patients. J Am Soc Nephrol. 2005;16(11):3365-70. https://doi.org/10.1681/ASN.2004090740

3. Mehta RL, Kellum JA, Shah SV, Molitoris BA, Ronco C, Warnock DG, et al. Acute Kidney Injury Network: report of an initiative to improve outcomes in acute kidney injury. Crit Care 2007;11(2): R31. https://doi.org/10.1186/cc5713

4. Kellum JA, Mehta RL, Levin A, Molitoris BA, Wranock DG, Shah SV, et al. Development of a clinical research agenda for acute kidney injury using an international, interdisciplinary, three-step modified Delphi process. Clin J Am Soc Nephrol. 2008;3(3):887-94. https://doi.org/10.2215/CJN.04891107

5. Tuglular SZ. [Acute Problems in Calcium and Phosphorus in Renal Disease Setting] (in Turkish). Turk Clin J Nephrol-Special Topics 2010;3(1):50-5.

6. Thongprayoon C, Cheungpasitporn W, Mao MA, Sakhuja A, Erickson S. Admission Calcium levels and risk of acute kidney injury in hospitalised patients. Int J Clin Pract 2018;72(4):e13057. https://doi.org/10.1111/ijcp.13057

7. Khwaja A. KDIGO Clinical Practice Guideline for Acute Kidney Injury. Kidney Int. Supplements 2012;2:1-138. https://doi.org/10.1038/kisup.2012.6

8. Assadi F. Hypercalcemia: an evidence-based approach to clinical cases. Iran J Kidney Dis 2009;3(2):71-9. https://pubmed.ncbi.nlm.nih.gov/19395781/

9. Higaki M, Tanemoto M, Shiraishi T, Taniguchi K, Fujigaki Y, Uchida S. Acute Kidney Injury Facilitates Hypocalcemia by Exacerbating the Hyperphosphatemic Effect of Muscle Damage in Rhabdomyolysis. Nephron 2015;131(1):11-6. https://doi.org/10.1159/000437391

10. Akman C, Cakır DÜ, Bakirdogen S, Balc1 S.The effect of serum calcium levels on uremic encephalopathy in patients with acute kidney injury in the emergency department. Medicina 2019;55(5):204. https://doi.org/10.3390/medicina55050204

11. Bellomo R, Kellum JA, Ronco C, Wald R, Martensonn J, Maiden M, et al. Acute kidney injury in sepsis. Intensive Care Med 2017; 43(6):81628. https://doi.org/10.1007/s00134-017-4755-7

12. Shao M, Wang S, Parameswaran PK. Hypoalbuminemia: a risk factor for acute kidney injury development and progression to chronic kidney disease in critically ill patients. Int Urol Nephrol 2017;49(2):295-302. https://doi.org/10.1007/s11255-016-1453-2

13. Wiedermann CJ, Wiedermann W, Joannidis M. Causal relationship between hypoalbuminemia and acute kidney injury. World J Nephrol. 2017;6(4):176-87. https://doi.org/10.5527/wjn.v6.i4.176

14. Wiedermann CJ, Joannidis M. Nephroprotective Potential of Human Albumin Infusion: A Narrative Review. Gastroenterol Res Pract 2015; 912939:8 . http://dx.doi.org/10.1155/2015/912839 